\title{
Imagens de aprendizagem e ensino na arte fune- rária gótica: a propósito de uma cena escolar no túmulo do rei D. Pedro I de Portugal
}

Luís U. Afonso

Instituto de História da Arte. Universidade de Lisboa

Resumen: El arte de los monumentos funerarios de los siglos XIII y XIV nos permite seguir el desarrollo de la noción de individuo al final de la Edad Media, principalmente, a través de la aparición de las estatuas yacentes, de la ampliación progresiva de los tipos sociales que ellas representan y del desarrollo de las imágenes alusivas al cursus vitae del enterrado, donde se incluían, a veces, algunas escenas escolares. A partir de una pequeña escena de este tipo, esculpida en el túmulo del rey don Pedro I de Portugal, realizado alrededor de 1361-1363, se ha procurado comprender cual es la relación existente entre el fomento de la noción de individuo en el mundo gótico y la producción de imágenes de enseñanza y aprendizaje en el arte funerario y cuales son las intenciones asociadas a la producción de estas escenas escolares en la misma época.

Palabras clave: D. Pedro; arte funerario; biografía; aprendizaje; enseñanza; iconografía; gótico; Alcobaça; individuo; túmulo.

ABstRact: The funerary art of the 13th and 14th centuries allow us to follow the development of the notion of the individual in the late middle ages, namely through the appearance of the gisants, the enlargement of the social types that they represented and the development of images referring to the cursus vitae of the deceased, where school scenes were included on occasion. Beginning with a small scene of this type sculpted in the tomb of King Pedro I of Portugal, produced c.1361-63, we attempt to understand the relation between the increment of the notion of the individual in the Gothic world and the production of images of teaching and learning in funerary art, and which were the intentions associated to the production of these school scenes in the same epoch.

Keywords: D. Pedro; funerary art; biography; learning; teaching; iconography; Gothic; Alcobaça; individual; tomb.

\section{INTRODUÇÃO}

Este estudo tem como ponto de partida uma pequena cena escolar esculpida no túmulo do rei D. Pedro I de Portugal, uma obra realizada entre c.1361 e c.1363 na igreja da abadia cisterciense de Alcobaça. A partir deste monumento tentamos compreender a interação verificada entre o desenvolvimento da noção de indivíduo no mundo gótico e a produção de imagens de ensino e aprendizagem na arte funerária dos séculos XIII e 
XIV, explorando quais os objetivos ligados à produção deste tipo de representações. Como iremos ver, estas imagens veiculavam discursos biográficos apologéticos que tanto serviam para enaltecer a identidade de classe e a posição social do tumulado, e da respetiva linhagem, como serviam para sedimentar determinadas culturas e identidades institucionais, pelo que é necessário tentar clarificar o modo como se relacionavam estas variáveis.

\section{BIOGRAFIAS, EXEMPLA CÍVICOS E ARTE FUNERÁRIA NO FINAL DA IDADE MÉ- DIA}

O progressivo incremento da noção de indivíduo no final da Idade Média exprimiuse, e construiu-se, através de complexas práticas sociais e de variados tipos de textos e imagens. ${ }^{1} \mathrm{Na}$ literatura, um dos aspetos mais evidentes desta tendência encontra-se na ampliação e aperfeiçoamento dos registos biográficos, autobiográficos e pseudobiográficos que estão bem documentados para os séculos XIII e XIV. ${ }^{2}$ De igual modo, desde c.1300 que se expandiu e aprofundou o interesse pelo topos dos homens e mulheres ilustres, especialmente cultivado nas cortes senhoriais e nos palazzi comunais das repúblicas italianas, recuperando-se, assim, uma relevante tradição romana. ${ }^{3}$ Utilizadas como exemplos éticos, mas quase sempre colocadas ao serviço de fins políticos e/ou propagandísticos, as vidas de tais homens

1 A. GOUREVITCH, La Naissance de l'Individu dans l'Europe Médiévale, Paris, 1997.

${ }^{2}$ B. STOCK, "The Self and Literary Experience in Late Antiquity and the Middle Ages", New Literary History, vol. 25, n. 4, 1994, pp. 839-852; L. DE LOOZE, Pseudo-biography in the Fourteenth Century. Juan Ruiz, Guillaume de Machaut, Jean Froissart, and Geoffrey Chaucer, Gainesville, 1997.

${ }^{3}$ M. SAGE, "The De Viris Illustribus: Chronology and Structure", Transactions of the American Philological Association, vol. 108, 1978, pp. 217-241; C. JOOSTGAUGIER, "The Early Beginnings of the Notion of "Uomini Famosi" and the "De Viris Illustribus" in Greco-Roman Literary tradition", Artibus et Historiae, vol. 3, n. 6, 1983, pp. 97-115. e mulheres ilustres foram longamente descritas e comentadas em livros. Os mais célebres e influentes textos deste género foram, provavelmente, o De viris illustribus de Petrarca, começado por volta de 1337-38, o De Casibus virorum illustrium de Boccaccio, redigido por volta de $1355-60$, e ainda o De mulieribus clarus, do mesmo autor, redigido inicialmente em torno de 1361-62, todos amplamente copiados e traduzidos, e em alguns casos iluminados, sobretudo ao longo do século $\mathrm{XV}{ }^{4}$

Com base neste tipo de textos criaram-se autênticas galerias de retratos, onde figuravam estas personagens célebres, mesclando-se, por vezes, com os líderes políticos do momento. Nas artes visuais estes ciclos desenvolveram-se, sobretudo, em pinturas murais e em tapeçarias. Em relação aos murais, uma das primeiras obras a ser realizada foi a série que Giotto pintou em Nápoles para o rei Roberto, entre 1328 e 1333, na Sala Regia do Castel Nuovo, representando um ciclo que reunia Alexandre, Salomão, Heitor, Eneias, Aquiles, Páris, Hércules, Sansão, César, e ainda quatro soberanas, a Rainha de Sabá, Andrómaca (rainha de Epiro), Dido e Cleópatra. ${ }^{5}$ Este conjunto de rainhas, colocadas em igualdade com os uomini famosi, visava sustentar a muito contestada pretensão de Roberto passar o trono para a sua filha, a princesa Joana. ${ }^{6}$ A Giotto é atribuída também outra série realizada para o palácio de

${ }^{4}$ J. RICHARDS, "Petrarch, Francesco", in J. TURNER (ed.), The Dictionary of Art, vol. 24, Nova Iorque, 1996, pp. 558-59; B. BUETTNER, Boccaccio's Des Cleres et nobles femmes. Systems of signification in an illuminated manuscript, Seattle, 1996, especialmente pp. 16-18; J. B. FRIEDMAN, "Boccaccio, Giovanni", in J. TURNER (ed.), The Dictionary of Art, vol. 4, 1996, pp. 196-97.

C. JOOST-GAUGIER, "Giotto's Hero Cycle in Naples: A Prototype of Donne Illustri and a Possible Literary Connection", Zeitschrift für Kunstgeschichte, vol. 43, n. 3, 1980, pp. 311-318.

${ }^{6}$ B. CASSIDY, "Politics and propaganda in Late Medieval Italian Mural painting: some themes", in L. AFONSO E V. SERRÃO (eds.), Out of the Stream: studies in Medieval and Renaissance mural painting, Newcastle, 2007, pp. 260-290, especificamente pp. 278-81. 
Azzo Visconti, em Milão, onde este signore figurava ao lado de Hércules, Heitor, Átila e Carlos Magno, ${ }^{7}$ enquanto em Pádua, no Palácio Carrara, um ciclo do mesmo tipo, elaborado por volta de 1367-79, terá beneficiado bastante da relação de proximidade entre Petrarca, Altichiero e o encomendante, Francesco da Carrara. ${ }^{8}$ Em relação às tapeçarias destacamos o sucesso obtido pelos panos representando os Nove Heróis, ou Nove Valentes, designadamente Heitor, Alexandre, César, Josué, David, Judas Macabeu, Artur, Carlos Magno e Godofredo de Bulhão, todos eles tomados como modelos a seguir no âmbito da cultura cavaleiresca da época. Podemos ter uma ideia deste tipo de têxteis a partir de um conjunto de fragmentos conservado no Metropolitan Museum de Nova Iorque, que originalmente formavam três tapeçarias produzidas no sul dos Países Baixos por volta de $1400-10{ }^{9}$

Em todo o caso, talvez seja ao nível da arte funerária que melhor se pode identificar a profunda viragem no sentido da individualização do sujeito, devido às profundas mudanças operadas no culto dos mortos, nomeadamente com o aparecimento dos jacentes e o progressivo alargamento dos tipos sociais que representavam. ${ }^{10}$ É precisamente neste

${ }^{7}$ Ibidem, pp. 278-79.

8 T. MOMMSEN, "Petrarch and the Decoration of the Sala Virorum Illustrium in Padua", Art Bulletin, vol. 34, n. 2, 1952, pp. 95-116; J. RICHARDS, "Petrarch, Francesco", p. 559.

${ }^{9}$ J. J. RORIMER e M. B. FREEMAN, "The Nine Heroes Tapestries at the Cloisters", The Metropolitan Museum of Art Bulletin, vol. 7, n. 9, 1949, pp. 243-260; A. S. CAVALLO, Medieval Tapestries in the Metropolitan Museum of Art, Nova Iorque, 1993, especialmente pp. 94-124.

${ }^{10}$ K. BAUCH, Das mittelalterliche Grabbild. Figürliche Grabmäler des 11. Bis 15. Jahrhunderts in Europa, Berlim, 1976; E. PANOFSKY, Tomb Sculpture. Four lectures on its changing aspects from Ancient Egypt to Bernini, Londres, 1992, nomeadamente pp. 53-59. Para o panorama peninsular veja-se Á. FRANCO MATA, "Iconografia funerária gótica en Castilla y León (siglos XIII y XIV)", De Arte, n.2, 2003, pp. 47-86; J. C. VIEIRA DA SILVA, "Memória e Imagem: reflexões sobre escultura tumular portuguesa (séculos XIII e XIV)", Re- período, de facto, que se alargam os tipos tradicionais, dedicados à coroa, à aristocracia e ao alto clero, surgindo também pela primeira vez os jacentes dedicados ao burguês endinheirado, ao magistrado, ao herói militar ou ao letrado, uma figura que em alguns casos acumulava tal estatuto com o domínio das belas letras, especialmente em Itália durante o Trecento. Alguns dos monumentos funerários destes letrados representam $\mathrm{O}$ tumulado ex cathedra, lecionando uma aula diante de um grupo de estudantes universitários. ${ }^{11}$ Estas representações, que designamos como imagens de ensino, ${ }^{12}$ funcionavam como um atributo, semelhante ao báculo no túmulo de um bispo ou uma espada no túmulo de um nobre. Uma situação diferente, também com expressão na arte sepulcral, diz respeito àquilo que designamos como imagens de aprendizagem, um tipo de imagem que se desenvolve no âmbito das conceções medievais do ciclo de vida do ser humano, amplamente meditadas e teorizadas durante os séculos XIII e XIV. ${ }^{13}$ Efetivamente, tal como sucedia na Antiguidade, onde o cursus vitae de um indivíduo podia ser recordado de forma breve no respetivo túmulo, através da representação idealizada de alguns momentos representativos da sua vida, no mundo gótico encontramos diversas evidências da retoma desta prática. ${ }^{14}$

vista de História da Arte, n. 1, 2005, pp. 46-81; IDEM, "A construção de uma imagem: jacentes de nobres portugueses do século XIV", El Intercambio Artístico entre los Reinos Hispanos y las Cortes Europeas en la Baja Edad Média, C. COSMEN ALONSO, M. V. HERRÁEZ ORTEGA Y M. P. GÓMEZ-CALCERRADA (eds.), León, 2009, pp. 407-429.

${ }^{11}$ R. GRANDI, I Monumenti dei Dottori e la Scultura in Bologna (1267-1348), Bologna, 1982; B. CASSIDY, Politics, Civic Ideals and Sculpture in Italy. c.12401400, Londres, 2007, pp. 144-145.

${ }^{12}$ Mais adiante explicamos de forma detalhada o que entendemos por "imagens de ensino".

${ }^{13}$ E. SEARS, The Ages of Man: Medieval Interpretations of the Life Cycle, Princeton, 1986; M. GOODICH, From Birth to Old Age. The human life cycle in medieval thought, 1250-1350, Lanham, 1989.

${ }^{14}$ L. U. AFONSO, "Eros et Thanatos: the tomb of king Pedro in Alcobaça and its Wheel of Life and For- 


\section{A EDUCAÇÃO DO PRÍNCIPE E AS IMAGENS DE APRENDIZAGEM}

Numa das edículas da Roda da Vida e da Fortuna do túmulo do rei D. Pedro I de Portugal, ${ }^{15}$ realizado no Mosteiro de Alcobaça por volta de 1361-63, encontra-se uma cena de aprendizagem com cinco personagens (Fig. 1). Esta pequena composição apresenta dois homens adultos em pé, em posição frontal, vestindo trajes longos, de tipo clerical. Actualmente estas duas figuras já não possuem cabeça, pelo que se perderam muitos indicadores expressivos que nos poderiam dar uma ajuda preciosa para o entendimento desta cena. Ainda assim, o modo como a composição está construída indica que estas figuras assumiam o papel de mestres de um grupo de educandos sentado à sua frente, uma cena que não seria estranha à vida escolar do próprio mosteiro, o maior e o mais importante da Ordem de Cister em Portugal. Um dos mestres representados na edícula puxa a orelha a um dos estudantes, enquanto a posição do corpo do outro professor indicia que segurava algo nas mãos, talvez um códice aberto.

Os três estudantes aqui representados estão esculpidos num plano mais próximo. São todos muito jovens e estão sentados no chão ou sobre pequenas almofadas. Cada um deles tem o corpo virado para uma direcção diferente, conseguindose alcançar, na fusão das três imagens, a percepção cinética de uma escultura em ronde bosse, mostrada em três de quatro ângulos equidistantes. No entanto, estes jovens estudantes têm características faciais distintas e são apresentados com gestos e expressões bem diferentes. Embora o jovem do meio se encontre de costas para nós, nota-se perfeitamente a atenção que dedica ao desenrolar da lição, parecendo estender a mão direita para um livro, ou caderno,

tune (1358-1363)", Artibus et Historiae, n. 65, 2012, pp. $9-41$.

${ }^{15}$ L. U. AFONSO, O Ser e o Tempo. As idades do homem no gótico português, Casal de Cambra, 2003, pp. 23-103. que segura sobre as pernas. O jovem do lado esquerdo, por sua vez, é apresentado sem cabelo, com uma fisionomia simiesca, deformada, com covas no lugar dos olhos, levando infantilmente uma mão à boca. $\mathrm{O}$ ar imbecil deste estudante é confirmado pelo castigo que um dos mestres lhe inflige, puxando-lhe a orelha direita, adivinhandose, para breve, o recurso à verdasca que o mesmo mestre segura junto ao peito, em diagonal. O rosto desta figura, aliás, tem semelhanças com o modo como os escultores dos túmulos de D. Pedro e D. Inês representaram algumas figuras tenebrosas, designadamente o pequeno demónio-bebé que substitui S. Bartolomeu no berço (Fig. 2), no frontal direito da arca de D. Pedro I, ou a cabeça da metade monstruosa da Fortuna, na mesma testeira da Roda da Vida e da Fortuna onde está a cena de aprendizagem, ou ainda o diabo de três cabeças, duas das quais nas nádegas, que empurra os condenados para a Boca do Inferno no Juizo Final esculpido no facial dos pés da arca de D. Inês de Castro. ${ }^{16}$

Finalmente, o terceiro estudante, que assume uma pose mais madura e senhorial, é apresentado como o mais sábio dos três jovens. Esta figura apresenta-se reclinada, de perna cruzada, e ampara o braço direito sobre a mão esquerda, com a qual apoia o rosto, prefigurando o gesto meditativo utilizado por Rodin em $O$ Pensador ou a típica expressão contemplativa da Melancolia de Dürer e outros. Como referiu Serafim Moralejo, entre os três estudantes, será este quem poderá representar com mais probabilidade o próprio príncipe D. Pedro, em cujo túmulo esta cena de aprendizagem está esculpida. ${ }^{17}$

${ }^{16}$ Uma obra realizada em Alcobaça um pouco antes, entre c.1358 e c.1360, e colocada no transepto da igreja, lado a lado com o túmulo de D. Pedro. Ibidem, pp. 2425 e $79-80$.

17 S. MORALEJO, "El 'Texto' Alcobacense sobre los Amores de D. Pedro y D a Inês", in A. NASCIMENTO e C. RIBEIRO (eds.), Actas do IV Congresso da Associação Hispânica de Literatura Medieval (Lisboa, 1-5 de Outubro de 1991), Lisboa, 1993, vol. I, 71-89, especificamente p. 75 . 
Esta cena constitui um dos passos da Roda da Vida e da Fortuna, patente na testeira do túmulo do rei D. Pedro I, dividida em doze cenas, no rodado exterior, e em seis cenas, no rodado interior (Fig. 3). ${ }^{18}$ As primeiras seis cenas do exterior correspondem à iconografia convencional das Idades do Homem, ou seja, uma forma estereotipada de representar as diferentes etapas da vida do ser humano através de uma série de atividades próprias de cada uma dessas fases. $\mathrm{Na}$ primeira cena temos um episódio doméstico, passado junto à lareira, com uma panela ao lume, onde uma mãe pega num bebé ao colo. Na segunda cena temos a representação da cena escolar que tem prendido a nossa atenção. As cenas seguintes representam a adolescência e os seus amores, continuando-se este tipo de representações até à figuração do cadáver, na última cena, fechando-se, pois, um ciclo que liga o nascimento à morte.

Mesmo tendo em conta que este ciclo escultórico obedece a um conjunto de regras e convenções iconográficas, é notório que a obra joga com a ambiguidade entre a apresentação de um modelo geral, universalista, aplicável a qualquer ser humano, e a apresentação de uma história de vida em particular, referente à biografia do tumulado. Na interpretação destas esculturas, de facto, está-se permanentemente a praticar um jogo de associação / dissociação entre o geral e o particular. Ou seja, uma ponderação constante entre um modelo genérico e a sua aplicabilidade à vida do rei D. Pedro I, criando-se um estado de incerteza que favorece o prolongamento do efeito da obra na memória do observador. De qualquer modo, o que nos move neste estudo não são estas questões, que abordámos noutros locais, ${ }^{19}$ mas sim a especificidade da cena de aprendizagem como uma forma convencional de representar uma etapa do cursus vitae.

\footnotetext{
${ }^{18}$ L. U. AFONSO, O Ser e o Tempo, pp. 23-55.

${ }^{19}$ L. U. AFONSO, “Eros et Thanatos...", pp. 17-19.
}

\section{O CURSUS VITAE E AS IMAGENS DE} APRENDIZAGEM

$\mathrm{Na}$ arte gótica subsistem diversos exemplos em que a puerícia, ou meninice, é representada através de uma cena escolar. ${ }^{20}$ É este o caso, por exemplo, de um capitel octogonal existente na galeria térrea do Palácio dos Doges, em Veneza, representando sete Idades do Homem, onde esta etapa da vida é ilustrada através de uma criança a estudar (Fig. 4). ${ }^{21}$ Esculpido por volta de 1342-48, este capitel tem a particularidade de apresentar uma inscrição em cada face onde se associam as Idades do Homem à influência dos planetas. Neste caso, a escultura mostranos um moço estudando por um livro, onde se reconhecem as primeiras onze letras do alfabeto. A inscrição que acompanha a escultura apresenta o seguinte texto: “ $M E(R)$ CUREU(S) D(OMI)N(A)T PUERICIE P(ER) $\mathrm{AN}(\mathrm{N}) \mathrm{O}(\mathrm{S}) \mathrm{X}^{\prime \prime}$. Ou seja, o planeta Mercúrio domina/tutela a puerícia durante dez anos.

Noutras faces do mesmo capitel veneziano insiste-se, novamente, na associação entre as fases da vida e as ideias de aprendizagem e literacia, na medida em que também a adolescência, outra etapa da vida, é representada por um jovem a estudar por um livro, desta vez uma obra de aritmética, pois são números, e não letras, que figuram no manuscrito aberto sobre o colo (Fig. 5). A inscrição que acompanha esta imagem diz-nos que é Vénus, a deusa do amor, quem tutela esta fase da vida, como é habitual nestes ciclos, mas criando uma rara associação entre a aritmética e os amores. Neste caso parece-nos que a intenção dos escultores, e/ ou dos encomendantes, terá sido a de apontar para a sequencialidade etária dos estudos, partindo do trivium, com as suas disciplinas discursivas, da palavra, para o quadrivium, com as suas disciplinas mais abstratas, do número. Finalmente, na penúltima fase

${ }^{20}$ E. SEARS, The Ages of Man, pp. 101, 109-111.

21 A. LERMER, Der gotische "Dogenpalast" in Venedig. Baugeschichte und Skulpturenprogramm des Palatium Communis Venetiarum, Munique, 2005. 
da vida, entre a senectude e a decrepitude, dominada por Júpiter, voltamos a encontrar um homem com um livro aberto diante de si, podendo tratar-se de um livro de astrologia, se o passar dos anos for acompanhado pelo estudo de matérias mais complexas, ou de um livro de natureza religiosa, preparando o último rito de passagem. No caso desta escultura não estamos perante uma ilustração específica do cursus vitae de uma pessoa, pois este capitel, à semelhança de dezenas de outros do Palazzo Ducale, insere-se num projecto semi-enciclopédico, ou melhor, caleidoscópico, que usa os capitéis octogonais para combinar temas de grande diversidade, maioritariamente seculares, ao longo do perímetro térreo das alas sul e poente do edifício-sede da república veneziana.

Uma situação diferente, porém, diz respeito ao túmulo do bispo Giles de Bridport, reputado pedagogo e prelado, que liderou a diocese inglesa de Salisbury entre 1256 e $1262 .{ }^{22}$ Apesar de não ter participado na renovação arquitetónica desta imponente catedral gótica, Giles de Bridport fundou um importante e prestigiado colégio associado a esta instituição. Realizado já depois do seu passamento, o túmulo em causa é uma espécie de templete retangular formado por arcadas longitudinais e encaixado entre dois pilares do transepto da catedral. Esta solução permite observar facilmente a arca e o jacente do bispo, ambos pouco elevados em relação ao pavimento. Um dos aspectos mais originais deste monumento diz respeito às oito esculturas em alto-relevo que ocupam as enjuntas das arcadas do templete, quatro de cada lado, todas elas referentes ao cursus vitae do bispo. No lado sul do templete representa-se uma cena de natividade seguida por uma cena escolar com uma criança, sendo a sequência continuada por outra cena escolar com alguns jovens (Fig. 6) e por uma cena com dois homens em diálogo. No lado norte representa-se uma cena com um

${ }^{22}$ M. E. ROBERTS, "The Tomb of Giles de Bridport in Salisbury Cathedral", Art Bulletin, vol. 65, 1983, pp. 559-586. bispo e várias figuras ajoelhadas, outra cena com quatro bispos, uma cena com um bispo deitado sobre um leito e, finalmente, a elevatio animae. Marion Roberts interpretou estas oito imagens como a ilustração da biografia do bispo Giles, desde o momento do nascimento até à ascensão da sua alma ao paraíso. ${ }^{23}$ As esculturas em alto-relevo que medeiam estes dois momentos representam algumas etapas da formação escolar do bispo, a sua nomeação como arcediago e como bispo, e finalizam com a preparação dos seus rituais fúnebres. Tanto quanto se sabe, Giles de Bridport nunca teve fama de santidade nem foi objecto de devoção popular. Deste modo, excluindo a hipótese hagiográfica, Roberts sugere que este discurso biográfico tenha sido encomendado a posteriori para destacar a vida exemplar de Giles de Bridport enquanto religioso e pedagogo. Ou seja, terá sido, muito provavelmente, uma forma de os seus sucessores na direcção do colégio destacarem a figura do fundador e a excelência da formação oferecida aos estudantes. ${ }^{24}$

\section{UMAIMAGEM É UMA IMAGEM É UMA IMAGEM...}

Uma das características dos registos biográficos medievais, em letra ou em imagem, é o facto de construírem discursos que jogam na ambiguidade entre a convenção generalista e a particularidade de uma situação concreta, contando-se esta através daquela, como sucede nos túmulos do rei D. Pedro I de Portugal e do bispo Giles de Bridport. De qualquer modo, estas representações, referentes a imagens de aprendizagem, não foram, nem nunca o pretenderam ser, imagens "realistas", no sentido contemporâneo. Não podem ser encaradas como uma espécie de cristalização da realidade, uma "fotografia", a respeito dos processos de ensino e aprendizagem, ainda que nos possam dar informações importantes sobre a cultura escolar e sobre os processos de ensino da época em

\footnotetext{
${ }^{23}$ Ibidem, pp. 578-583.

${ }^{24}$ Ibidem, pp. 583-584.
} 
que foram produzidas. Estas imagens, como todas as outras, têm um lastro iconográfico muito pesado na sua origem, no processo da sua execução e, claro, na forma como os sujeitos operam a receção dessas obras. São imagens geradas, e interpretadas, pois, a partir de outras imagens, muito mais, incomparavelmente mais, do que imagens geradas a partir da observação da realidade ou da sua representação ficcionada. ${ }^{25}$ Todavia, esta situação não invalida a existência de exceções à norma. É esse o caso, por exemplo, das iluminuras realizadas em Oxford por William De Brailes, por volta de 1230, num manuscrito que agrega alguns livros da lógica aristotélica. Conforme sublinhou Michael Camille, as iniciais pintadas na abertura dos diferentes livros reproduzem com alguma fidelidade o público estudantil próprio do estádio de aprendizagem associado a cada livro, nomeadamente através da adequação da idade e do comportamento dos alunos face ao conteúdo das ditas obras. ${ }^{26}$

A diferença entre imagens de ensino e imagens de aprendizagem nem sempre é óbvia, embora na arte funerária seja mais simples esta clarificação. Isto porque a dissemelhança entre ambas não radica nas imagens em si mesmas, mas sim no seu referente, na sua escala e no seu contexto topográfico e narrativo. Ou seja, no caso de estarmos perante uma imagem de alguém que não fez carreira de académico é impossível encontrarmos uma imagem de ensino. O mais natural é tratar-se de uma imagem de aprendizagem, pois o referente é sempre o sujeito que aprende. Este tipo de imagens reporta-se a uma fase inicial da formação do indivíduo, situada na meninice ou na adolescência, onde há um professor e vários estudantes mais jovens.

\footnotetext{
${ }^{25}$ Referimo-nos, neste caso, às vetustas teses de Émile Mâle e Louis Réau sobre a influência da liturgia, do teatro litúrgico e da homilética para o desenvolvimento da iconografia religiosa medieval. L. RÉAU, Iconographie de l'Art Chrétien, vol. 1, Paris, 1955, pp. 254-266.

${ }^{26}$ M. CAMILLE, "An Oxford University Textbook Illuminated by William de Brailes", Burlington Magazine, vol. 137, n. 1106, 1995, pp. 292-299.
}

São imagens de escala mais reduzida, integradas em sequências narrativas mais amplas. Por sua vez, as imagens de ensino têm por referente o sujeito que ensina, o que apenas é possível, em princípio, no caso de o defunto ter sido professor. Nesta situação representa-se um docente sentado perante um ou vários estudantes, os quais são sempre mais velhos do que sucede nas imagens de aprendizagem. Além disso, este tipo de cena costuma ser representado de forma autónoma, numa escala superior à das imagens de aprendizagem e fora de uma sequência narrativa. Estas imagens referemse, quase sempre, ao ensino universitário, o que é compreensível face à natureza das memórias funerárias, como veremos mais adiante quando tratarmos alguns túmulos bolonheses.

Parece-nos, pois, que o procedimento mais correto a respeito da dicotomia imagens de ensino / imagens de aprendizagem será considerar as primeiras, por defeito, como aquelas onde mestres e estudantes surgem no mesmo espaço escolar e onde não existem informações sobre o referente - ou onde este é nitidamente o professor. Em contrapartida, só devem classificar-se como imagens de aprendizagem aquelas onde o referente é indiscutivelmente o sujeito que aprende.

É claro que este tipo de classificação abrange apenas uma pequena parte das imagens utilizadas em associação ao ensino, como sucedia com as imagens que visavam identificar um determinado lugar como um espaço escolar. Estas imagens de identificação podiam ser constituídas por alegorias e personificações, como sucedia com as pinturas que o Infante D. Henrique mandou fazer na Universidade de Lisboa em 1431.27 Neste caso, procurava-se associar a tutela simbólica de um espaço de saber a determinados signos visuais. Os processos cognitivos de enriquecimento intelectual e disciplinar que decorriam nesses locais

${ }^{27}$ L. U. AFONSO, "A imagem do saber: as pinturas da Universidade de Lisboa em 1431", Olisipo. Boletim do Grupo "Amigos de Lisboa", n. 27, 2007, pp. 10-19. 
eram, assim, colocados sob a alçada de uma autoridade fundadora, ou seminal, como sucedia com as imagens de Galeno e Aristóteles nas pinturas da Universidade de Lisboa. Noutros casos, as imagens podiam assumir uma dimensão mais ambígua, mais difícil de interpretar, operando visualmente por metáforas, elipses, metonímias e sinédoques em referência a práticas usadas no ensino, como as alusões mais ou menos diretas à disputatio, à dialética e à domesticação dos pensamentos e impulsos irracionais, como ocorria, aparentemente, num tímpano românico produzido por volta de 1160 que se julga ter pertencido a uma escola administrada pelo cabido da Catedral de Reims destinada a adolescentes leigos. ${ }^{28}$

Regressando, porém, às duas classificações que apresentámos anteriormente, podemos verificar que na Antiguidade também se produziram várias obras com cenas de aprendizagem, sendo mais difícil perceber os casos que se referem ao ensino. $\mathrm{O}$ primeiro tipo de imagens surge com alguma frequência nos designados "sarcófagos biográficos", um dos vários géneros tumulares que se desenvolveram em Roma a partir dos inícios do século II d.C. quando os enterramentos passaram a ser preferidos à cremação. ${ }^{29}$ Nalguns destes sarcófagos a imagem de aprendizagem é utilizada para ilustrar uma fase inicial da vida do tumulado, como sucede no sarcófago de Marcus Cornelius Statius, realizado em Óstia nos meados do séc. II d.C. e atualmente conservado no Museu do Louvre. ${ }^{30}$ Este sarcófago ilustra quatro etapas da vida do jovem Marco, no-

${ }^{28}$ M. CAMILLE, "«Seeing and lecturing»: disputation in a twelfth-century tympanum from Reims", in E. SEARS e T. THOMAS, Reading Medieval Images. The art historian and the object, s.l., 2002, pp. 75-87.

${ }^{29}$ N. B. KAMPEN, "Biographical narration and Roman funerary art", American Journal of Archaeology, vol. 85, n. 1, 1981, pp. 47-58; E. PANOFSKY, Tomb Sculpture, pp. 31-35; J. HUSKINSON, “Constructing childhood on Roman funerary memorials", Hesperia Supplements, vol. 41, 2007, pp. 323-338.

30 Sarcófago de Marcus Cornelius Statius. Mármore, séc. II, 47 x $143 \mathrm{~cm}$. Museu do Louvre, Departamento de meadamente o aleitamento do bebé, o menino ao colo do pai, o menino a conduzir um carro puxado por um bode ${ }^{31}$ e o menino de toga e rolo debatendo com o seu pai, como se estivesse diante de um pedagogo. Outro sarcófago romano, um pouco mais tardio, mostra-nos parte do cursus vitae de outro jovem. ${ }^{32}$ Dividido em três cenas, o sarcófago exibe uma composição onde uma criança segue montada num carneiro atrelado a um veículo. Noutra cena o mesmo jovem, mas mais crescido, tem um rolo na mão, vestindo túnica e pallium, sendo acompanhado por quatro musas, uma das quais é Clio e outra Polímnia.

Nos casos antecedentes estamos, pois, perante imagens escolares utilizadas de forma semelhante à do túmulo do rei $\mathrm{D}$. Pedro I ou à do túmulo do bispo de Salisbury, em que estas etapas educacionais fazem parte de um discurso sobre o cursus vitae do tumulado. Em suma, se nestas situações podemos falar de um referente biográfico concreto, importa sublinhar que o mesmo tipo de imagens de aprendizagem pode surgir em representações comuns, universais, dedicadas à ilustração das diferentes fases da vida do ser humano, nomeadamente em diagramas que combinam as Idades do Homem com as Sete Artes Liberais, a exemplo do que sucede com a Árvore da Sabedoria (Arbor sapientiae) incluída em diversos exemplares góticos do Vrigiet de Solas. ${ }^{33}$

antiguidades gregas e romanas, MA 659 (Denon, Sala 25).

${ }^{31}$ Tratava-se de uma brincadeira habitual entre as crianças das classes altas, que conduziam carrinhos puxados por animais de pequeno porte, como cães e póneis. E. D'AMBRA, "Racing with Death: Circus Sarcophagi and the Commemoration of Children in Roman Italy", Hesperia Supplements, vol. 41, 2007, pp. 339-351.

32 Sarcófago de uma criança, com cenas da sua vida. Mármore, séc. III, 34 x $120 \mathrm{~cm}$. Museu do Louvre, Departamento de antiguidades gregas e romanas, MA 1520.

${ }^{33}$ Por exemplo, veja-se a iluminura do MS FR. 9220 da Biblioteca Nacional de Paris, fol. 16r. E. SEARS, The Ages of Man, pp. 142-43. 


\section{A INFLUÊNCIA DAS PERSONIFICAÇÕES DA GRAMÁTICA}

Uma das fontes mais relevantes para o estabelecimento das imagens de aprendizagem na época em estudo diz respeito, porém, à personificação da Gramática. A sedimentação dos seus atributos realizou-se ao longo do século XII, depois de se ter percorrido um longo caminho na representação desta arte liberal, especialmente no âmbito da sua associação à tradição textual das Núpcias de Mercúrio e da Filologia de Marciano Capela. ${ }^{34}$ Nesta obra redigida nos inícios do século $\mathrm{V}$, especificamente no Livro III, a Gramática é descrita como uma senhora idosa e elegante, nascida em Mênfis no tempo de Osíris, e que durante muitos anos viveu na Grécia, primeiro, e em Roma, posteriormente. De acordo com Capela, os atributos da Gramática eram uma paenula, isto é, o manto romano usado pelos oradores e pedagogos, e uma caixa medicinal, bem polida e de cuidada marcenaria, revestida a marfim, onde a Gramática possuía um conjunto de utensílios e mezinhas destinados a tratar as maleitas da língua, à semelhança de um físico habituado a tratar as maleitas do corpo. Tais utensílios e mezinhas, porém, eram maioritariamente constituídos por instrumentos e suportes para a escrita, com os quais se atingiria o domínio da linguagem e das suas regras. De acordo com Marciano Capela, na caixa existia uma faca de podar que permitia à Gramática "podar" os erros de pronunciação das crianças, sarando as feridas com uma tinta negra. Na caixa existia também um "medicamento" de cor vermelha, feito de erva-doce e pêlo de cabra, que devia ser aplicado na garganta quando se sofria de ignorância e pronúncia corrompida. Dentro da caixa havia ainda um "medicamento" apetitoso capaz de transformar a voz mais rude na mais

34 MARCIANO CAPELA, Martianus Capella and the Seven Liberal Arts, W. H. STAHL, R. JOHNSON e E. L. BURGE (eds.), Nova Iorque, 1977, vol. II, pp. 64-66. melodiosa. Outro "medicamento", à base de cera untada em madeira de faia e uma mistura de goma, nozes de galha e rolos de papiro, conseguia limpar os pulmões e vias respiratórias, além de ajudar as pessoas a recordarem-se melhor, prestarem mais atenção e estarem mais despertas. Finalmente, no interior da caixa havia ainda um instrumento para a limpeza dos dentes e da língua que eliminava os solecismos. Ou seja, por outras palavras, a Gramática é apresentada por Marciano Capela como uma hábil médica capaz de mudar a forma como a língua, a boca, os dentes e a respiração influenciam a expressão oral, e escrita, dos indivíduos.

É a partir desta longa descrição que se explicam algumas representações onde a Gramática surge representada com instrumentos e produtos mais próprios da medicina do que do ensino das letras. ${ }^{35}$ Algumas imagens do século XII mostram esta arte liberal a segurar uma escudela, um frasco de vidro flamejante ou um conjunto de ervas silvestres, atributos que remetem, precisamente, para esta alegoria da Gramática como uma arte que atua sobre o corpo por via de mezinhas e ablações. No reto de um fólio avulso dos finais do século XII a Gramática é apresentada como uma das sete artes alimentadas umbilicalmente pela Filosofia, tendo nas mãos uma pequena chave e uma taça larga. ${ }^{36}$ Estes atributos aludem, por um lado, ao facto de a Gramática ser a chave, ou base, para todo o conhecimento. Por outro lado, reportam-se também aos conhecimentos que a Gramática possui para preparar mezinhas "linguísticas" e à sua capacidade para nutrir as primeiras letras aos seres humanos. No verso deste fólio, aliás, a Gramática é representada junto a um fauno que traz plantas silvestres na mão, significando a natureza

35 L. CLEAVER, "Grammar and her children: learning to read in the art of the twelfth century", Marginalia, vol. 9, 2009, http://www.marginalia.co.uk/ journal/09education/cleaver.php.

36 Nova Iorque, Pierpont Morgan Library, MS M.982r (reto) e M.982v (verso). 
selvagem e a iliteracia do homem primitivo. A Gramática prepara-se para dar a beber, ou comer, a mezinha que está a moer com um pilão dentro de um almofariz, permitindo que o rude fauno se possa transformar num eloquente ser humano.

Outro caso igualmente interessante é ilustrado por uma iluminura alemã de finais do século XII, onde a Gramática surge acompanhada por Prisciano, um autor cujas gramáticas eram as mais seguidas na Idade Média, a par das de Donato. ${ }^{37}$ Nesta iluminura a Gramática agarra um pequeno frasco flamejante, sinal da potência dos ingredientes utilizados na confeção das mezinhas, e segura uma esclarecedora filactera onde se lê "Por mim alcança-se a eloquência e a arte de bem escrever". A mesma frase está representada num diagrama anicónico patente num exemplar manuscrito do De Musica, de Boécio, datado de inícios do século XII. ${ }^{38}$ Este diagrama está dotado apenas de indicações textuais distribuídas numa estrutura circular, em forma de rosácea, onde se indicam os atributos e as frases de cada uma das artes liberais. De acordo com Michael Masi, é provável que este diagrama tenha inspirado a ilustração das artes liberais que Herrade de Landsberg realizou por volta de 1180 no Hortus Deliciarum. ${ }^{39}$

Este tipo de representações, porém, foi francamenteminoritárioecedeu rapidamente o lugar a um outro tipo iconográfico, no qual a Gramática é representada isoladamente apenas com um livro e um flagelo, isto

37 Munique, Bayerisches Staatsbibliothek, Clm. 2599, f.102.

${ }^{38}$ Chicago, Newberry Library, MS F 9, fol. 65v.

${ }^{39}$ M. MASI, "A Newberry Diagram of the Liberal Arts", Gesta, vol. XI, t., 2, 1972, pp. 52-56. Há, no entanto, algumas diferenças entre os dois manuscritos. Por exemplo, a taça de onde saem chamas (cifum flammas emittentem), proposta no diagrama anicónico, é substituída por um flagelo e um códice na ilustração do Hortus, tratando-se de uma importante alteração no sentido do distanciamento da metáfora medicinal. Este manuscrito foi destruído na sequência da guerra Franco-Prussiana dos finais do século XIX, sobrevivendo apenas através de gravuras anteriores. é, um açoite (ou vergasta), dois atributos claramente associados ao ensino. ${ }^{40}$ É esta a forma utilizada, por exemplo, na ilustração da Gramática patente no diagrama das Sete Artes Liberais do Hortus Deliciarum de Herrade de Landsberg. O modelo iconográfico mais comum, de facto, mostra a Gramática como uma pedagoga de crianças segurando, com igual relevo, o livro e o açoite. Normalmente, é representada sentada, com véu e vestes longas, que lhe cobrem a totalidade do corpo, tendo junto de si uma ou mais crianças a quem transmite os rudimentos da língua escrita e falada.

É de acordo com este modelo que vemos a Gramática esculpida em diversos monumentos públicos românicos e góticos, como sucede nas fachadas ocidentais das catedrais de Chartres (c.1145-50) (Fig. 7), Sens (c.1170-1200), Laon (c.1190) e Auxerre (12801310). Na maior parte dos casos estas representações das artes liberais são feitas dentro do princípio da catedral gótica como uma summa visual do conhecimento, teológico e secular, tal como foi proposto, talvez com excessivo dogmatismo, por Émile Mâle nos inícios do século XX.41 Além destas esculturas, presentes nas catedrais francesas, são também bastante conhecidas as representações da Gramática na arte gótica italiana, como sucede com a representação patente na base da coluna central do púlpito da Catedral de Siena, uma obra esculpida por Nicola e Giovanni Pisano (1265-68), autores também dos múltiplos painéis em baixo-relevo da célebre Fonte de Perugia, entre os quais se inclui a personificação da Gramática, esculpida um

\footnotetext{
${ }^{40}$ Não devemos surpreender-nos com o recurso ao flagelo, em igualdade de circunstâncias com o livro. A Gramática servia também para educar os comportamentos, obrigando o estudante a adquirir uma atitude adequada à aquisição do conhecimento. A inquietude própria das crianças e dos adolescentes era, assim, domesticada à força de vergastadas aplicadas no tronco.

${ }^{41}$ É. MÂLE, L'art religieux du XIIIe siècle en France. Étude sur l'iconographie du Moyen Âge et sur ses sources d'inspiration, $6^{\underline{a}}$ ed., Paris, Armand Colin, 1925, pp. 75 e seguintes.
} 
pouco mais tarde (1277-78). Outra representação bastante conhecida encontra-se num dos medalhões em losango do Campanile de Florença, realizado sob a direção de Andrea Pisano (1343-47) segundo um projecto inicial de Giotto (1334-37).

Embora menos comuns, existem também várias personificações e alegorias envolvendo a Gramática em que esta arte é representada por uma figura masculina, em vez de uma mulher. ${ }^{42}$ Dois exemplos particularmente interessantes desta exceção encontram-se em iluminuras realizadas em França, nomeadamente numa ilustração da Image du Monde de Goussoin de Metz, realizada em $1277,{ }^{43}$ onde todas as artes liberais são representadas por figuras masculinas, e também numa ilustração de uma cópia tardia do Livre du Trésor de Brunetto Latini, realizada nos inícios do século XIV, cujo original data de c.1260, ${ }^{44}$ onde não só as artes liberais são integralmente representadas por figuras masculinas como entre catorze outras artes apenas a Tecelagem é representada por uma mulher. No primeiro caso, a imagem referente à Gramática mostra-nos um clérigo sentado, segurando um açoite na mão direita, tendo diante de si um grupo de quatro estudantes adolescentes, igualmente tonsurados, sentados no chão e vestindo apenas uma espécie de ceroulas deixando o torso descoberto para receberem as eventuais vergastadas do diligente mestre. A outra imagem está integrada numa iluminura de fólio inteiro que contempla a ilustração de vinte e uma artes diferentes, distribuídas em três colunas, incluindo matérias tão dissemelhantes como a Lógica, a Carpintaria ou a Necromancia. As artes liberais, que ocupam a coluna central, iniciam-se com uma

${ }^{42}$ M. EVANS, "Allegorical Women and Practical Men: the iconography of the artes reconsidered" in D. BAKER (ed.), Medieval Women, Oxford, 1978, pp. 305329.

43 Paris, Bibliothéque Ste. Geneviève, MS Ste. Geneviève 2200. Portanto, não muito depois da conceção do manuscrito original, em 1246.

${ }^{44}$ Londres, British Library, MS Add. 30024. imagem da Gramática ilustrada por um clérigo sentado numa cátedra com três crianças diante de si. Este clérigo pedagogo segura a cabeça de um aluno com a mão esquerda e com a direita levanta um açoite, com o qual se prepara para desferir um golpe no torso do estudante, de resto representado sem roupas, ao contrário dos outros dois colegas mais aplicados.

AS IMAGENS DE ENSINO E A APROPRIAÇÃO INSTITUCIONAL DA MEMÓRIA DOS DEFUNTOS

As imagens de ensino encontramse, essencialmente, na iluminura e na arte funerária. Neste último caso, tais imagens referem-se quase sempre ao passado académico de um letrado, representando-se o mestre sentado numa cátedra diante de um conjunto de estudantes universitários. É esta a situação, por exemplo, dos túmulos dos juristas Rolandino de Passeggeri (c.1305), em Bolonha, de Guglielmo di Ciliano (f.1324), em Siena, de Cino de Sighibuldi (f.1336), em Pistoia, ou do médico Ligo Ammannati (f.1359), em Pisa. ${ }^{45}$ De todos estes casos, provavelmente os mais eloquentes e extraordinários encontram-se na cidade de Bolonha. Como se sabe a autonomia desta comuna e a base da sua identidade cívica eram conferidas, sobretudo, pela notoriedade da sua universidade, atraindo estudantes de toda a Europa. ${ }^{46} \mathrm{O}$ reconhecimento e a fama da universidade eram assegurados pelo mérito dos seus professores de direito civil e canónico, os glossatori, pelo que se compreende a decisão desta república em levantar monumentos funerários em locais públicos dedicados aos seus mais destacados universitários. $\mathrm{O}$ arranque desta

${ }^{45}$ R. GRANDI, I Monumenti dei Dottori; A. MOSKOWITZ, Nicola Pisano's Arca di San Domenico and its Legacy, University Park Pennsylvania, 1994, pp. 3738; B. CASSIDY, Politics, Civic Ideals, pp. 144-145.

${ }^{46}$ Incluindo diversos estudantes portugueses. Sobre o assunto veja-se N. G. SILVA, "João das Regras e outros juristas portugueses da Universidade de Bolonha", Revista da Faculdade de Direito da Universidade de Lisboa, vol. XII, 1958, pp. 223-253. 
prática terá sido despoletado, porém, pelo impacto que teve em Bolonha nha conclusão do túmulo de S. Domingos de Gusmão (a Arca di San Domenico), uma obra realizada por Nicola Pisano entre 1264 e 1267, e nas potencialidades políticas e propagandísticas que os conventos mendicantes $\mathrm{e}$ as autoridades administrativas e escolares de Bolonha identificaram na arte sepulcral. ${ }^{47}$

O primeiro túmulo a ser realizado destes glossatori foi o de Odofredo Denari, iniciando uma prática que se prolongou até aos inícios do século XIV em Bolonha, escolhendo-se as praças das igrejas de $\mathrm{S}$. Francisco e de S. Domingos como os locais preferenciais para erguer estes monumentos. ${ }^{48}$ No âmbito desta política laudatória foram erguidos vários sepulcros como os dos juristas Odofredo Denari (c.1268), Rolandino dei Romanzi (c.1283-85) e Egidio Foscherari (c.1289), entre outros. ${ }^{49}$ Estes monumentos funerários bolonheses, erguidos ao ar livre, apresentam uma planimetria retangular e estão divididos em três registos. O registo inferior tem alguns metros de altura e consiste num plinto maciço ou num embasamento vazado, sendo constituído, neste caso, por um elevado número de colunas altas. No registo intermédio encontra-se a plataforma de sustentação e de apresentação da arca

${ }^{47}$ A. MOSKOWITZ, Nicola Pisano's Arca di San Domenico, p. 37. De resto, este período foi extremamente fértil ao nível das inovações na arte sepulcral italiana. É precisamente por esta altura, c.1270, que não só são elaborados os primeiros monumentos funerários góticos em Itália como também são introduzidos os primeiros jacentes à maneira francesa, sendo o caso mais precoce o túmulo do papa Clemente IV na igreja de S. Francesco em Viterbo. Sobre estas inovações veja-se I. HERKLOTZ, «Sepulcra» e «Monumenta» del Medioevo. Studi sull'arte sepolcrale in Italia, Napoli, 2001, pp. 205, 238-241.

48 Apesar do interesse dos mendicantes, especialmente dos dominicanos, em promover este tipo de túmulos sumptuosos, existiam vários obstáculos legais que os impediam de aceitar monumentos funerários no interior dos seus templos. A. MOSKOWITZ, Nicola Pisano's Arca di San Domenico, p. 37.

${ }^{49}$ R. GRANDI, I Monumenti dei Dottori, p. 107 e seguintes. propriamente dita. Este registo consiste em arcadas de arco quebrado com aduelas alternadamente brancas e verdes abertas nos quatro lados do monumento, o que permite ver a arca facilmente. Por último, a estrutura é rematada por um coroamento piramidal, revestido por ladrilhos verdes, tornando o conjunto ainda mais imponente na paisagem urbana.

No caso dos monumentos bolonheses mais antigos, como acontece com os túmulos de Egidio Foscherari e da família Denari (Accursio, Francesco e Odofredo), célebres glosadores jurídicos, a decoração das arcas é muito simples, apresentando apenas cruzes ou símbolos heráldicos, já que a monumentalidade se alcança através do mausoléu no seu conjunto. A partir do monumento funerário de Rolandino de Passeggeri, estruturalmente idêntico aos anteriores, inicia-se, porém, uma mudança muito significativa na decoração da arca funerária com a introdução de um novo tema iconográfico. ${ }^{50}$ Com efeito, numa das faces da arca deste académico os escultores incluíram uma cena onde Rolandino é representado em vida leccionando uma aula. A cena é toda ela construída em perfil, vendo-se o mestre sentado numa cátedra, numa das extremidades da composição, tendo diante de si um grupo de estudantes, representados em quatro fiadas sucessivas de mesas.

O monumento onde este tema se encontra mais desenvolvido, curiosamente, não se encontra em Bolonha, mas sim em Pistoia. Referimo-nos ao túmulo de Cino de Sighibuldi, ou Cino da Pistoia, um monumento erguido no interior da catedral dessa cidade que nos mostra uma dupla representação do famoso jurista imperial a ensinar um conjunto de discípulos (Fig. 8). ${ }^{51} \mathrm{~A}$ arca segue o modelo já referido a propósito de Rolandino, mas a sua iconografia é bastante mais desenvolvida. Aqui vemos o mestre

${ }^{50}$ R. GRANDI, I Monumenti dei Dottori, pp. 118119; A. MOSKOWITZ, Nicola Pisano's Arca di San Domenico, p. 38.

${ }^{51}$ B. CASSIDY, Politics, Civic Ideals, p. 145. 
sentado numa cátedra à frente de uma estante com um livro aberto, perante uma assembleia de nove estudantes sentados em mesas com três lugares cada. Sobre a arca o jacente dá lugar a um imponente grupo escultórico onde o jurista ocupa o centro da composição. Esculpido numa escala superior, sentado numa cátedra, Cino encontra-se ladeado por quatro estudantes representados numa escala mais reduzida, destacando-se, qual Cristo, perante os seus discípulos.

Em todos estes casos referentes a imagens de ensino, o modelo foi desenvolvido em paralelo com a iconografia utilizada em vários manuais universitários, especialmente os das disciplinas de direito, medicina e filosofia. Nessas obras universitárias foi comum incluir-se uma inicial ornamentada onde o lente, envergando as insígnias de mestre, surge sentado numa cátedra diante de uma plateia de estudantes sentados em bancos, no chão ou frente a mesas, acompanhando a dissertação do mestre ou esgrimindo argumentos dentro dos processos da disputatio. Este tipo de ilustrações pode ser encontrado, por exemplo, no manuscrito parcialmente iluminado por William de Brailes a que nos referimos anteriormente, dedicado à lógica aristotélica e realizado por volta de 1230, ou num fólio iluminado do Novela super Sexto, de Jean Andre, realizada em Itália no século $\mathrm{XIV},{ }^{52}$ ou ainda na representação de uma aula de Filosofia presente nas Grandes Chroniques de France, de inícios do século $\mathrm{XIV},{ }^{53}$ onde vemos um mestre sentado numa cátedra tendo à frente um grupo de estudantes sentados no chão. A interação entre este tipo de imagens e as imagens realizadas nos túmulos referidos é bastante evidente, tanto mais que o público-alvo de umas e outras era constituído, essencialmente, por estudantes universitários. fol.173.

52 Cambrai, Bibliothèque Municipale, MS 620,

\footnotetext{
${ }^{53}$ Castres, Bibliothèque Municipale, MS 116, f. 277 r.
}

\section{CONCLUSÃO}

A aplicação das imagens de ensino na tumulária está associada, quase sempre, a projetos de apropriação da fama e do prestígio intelectual do defunto, tanto mais que estes monumentos funerários eram exibidos em locais públicos de grande visibilidade, ao ar livre ou no interior de uma catedral. Esta situação torna-se especialmente evidente no caso de Bolonha, cuja universidade dependia enormemente da fama dos seus professores para sobreviver como uma escola de elite, especialmente no domínio do direito. Portanto, ao contrário da maior parte dos monumentos funerários que incluem imagens de aprendizagem, mais preocupados com a manutenção do estatuto social e a celebração da memória de um determinado indivíduo ou linhagem, isto é, mais centrados nos valores do sangue e da família, os monumentos funerários dedicados aos letrados testemunham a apropriação do prestígio (e do corpo) desses universitários, em benefício de uma identidade coletiva ou institucional, muitas vezes ligada à cidade onde os mesmos se tornaram célebres como mestres de um determinado ramo do conhecimento.

$\mathrm{Na}$ maior parte das situações conhecidas referentes aos sepulcros de letrados, a encomenda do túmulo e a seleção da respetiva iconografia foram feitas a posteriori, normalmente por membros da principal instituição que o tumulado integrou em vida. Ao contrário dos monumentos mais preocupados com o cursus vitae, onde as imagens de aprendizagem marcam apenas uma etapa da vida, pelo que se diluem entre um elevado número de cenas de tipo biográfico, este género de monumentos concentra-se apenas numa ou duas imagens de ensino desenvolvidas numa escala muito superior. São projetos de arte pública onde uma determinada instituição procura apropriar-se da memória e da aura do morto, nomeadamente no caso de colégios, universidades, cidades-estado ou dioceses, capitalizando a seu favor $\mathrm{o}$ prestígio associado ao letrado e recorrendo, 
literalmente, ao corpo desses académicos mais celebrizados para se promover.

Não podia ser maior, portanto, o contraste entre esta realidade e a cena alcobacense que está na origem deste texto (Fig. 1). Se no túmulo de D. Pedro I estamos diante de uma imagem de aprendizagem, representada dentro do esquema sequencial do cursus vitae, neste caso dividido em doze cenas, as imagens de ensino patentes nos monumentos italianos testemunham o carácter emblemático das mesmas, favorecendo a sua apropriação simbólica por parte de instituições com objetivos propagandísticos muito claros. No caso de Alcobaça, pelo contrário, a cena de aprendizagem visava marcar a sequência normal da formação de um jovem príncipe. Uma sequência interrompida de forma súbita e trágica através do violento assassinato de D. Inês de Castro, alterando por completo o sentido do cursus vitae do tumulado. Nesta situação, portanto, a imagem de aprendizagem é colocada ao serviço de um discurso perfeitamente individualizado, de pendor apologético, independentemente da genealogia iconográfica que a imagem tem atrás de si e em claro contraste com as imagens de ensino sabiamente fomentadas em Itália, cujos objetivos eram bastante diferentes. 


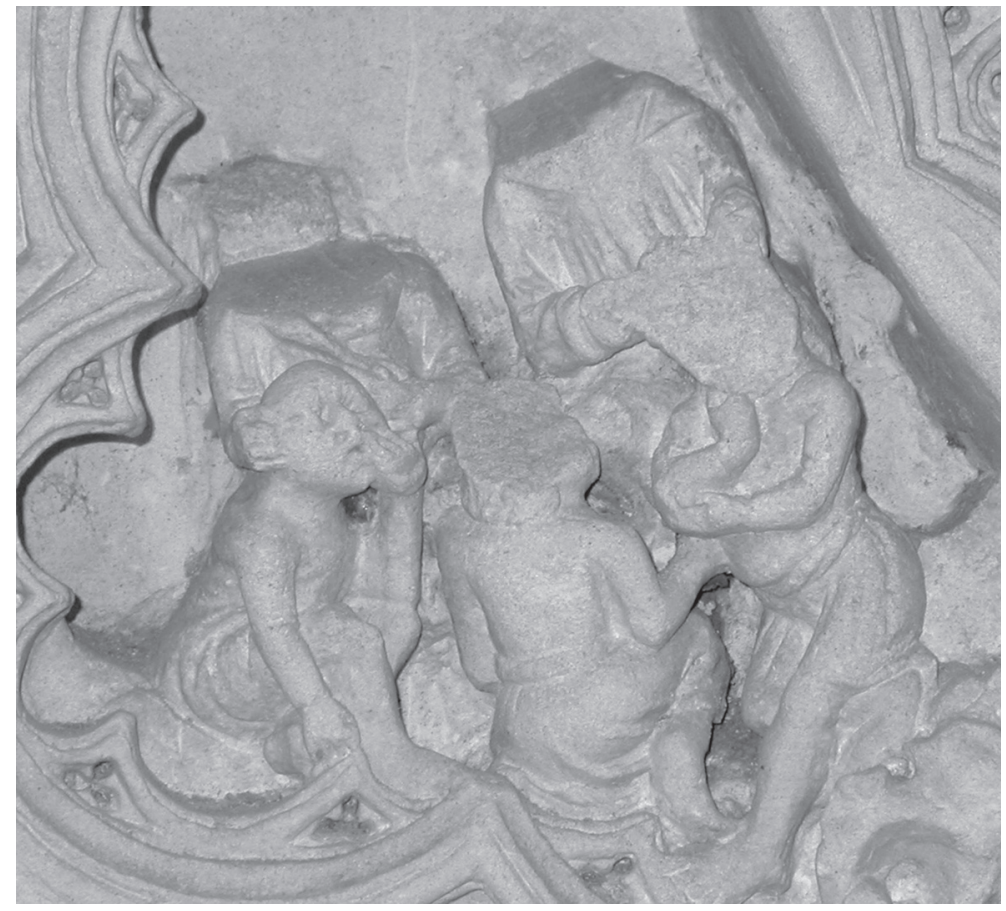

- Fig. 1. Imagem de aprendizagem. Roda da Vida e da Fortuna do túmulo do rei D. Pedro I, c.1361-63. Mosteiro de Alcobaça, Portugal.

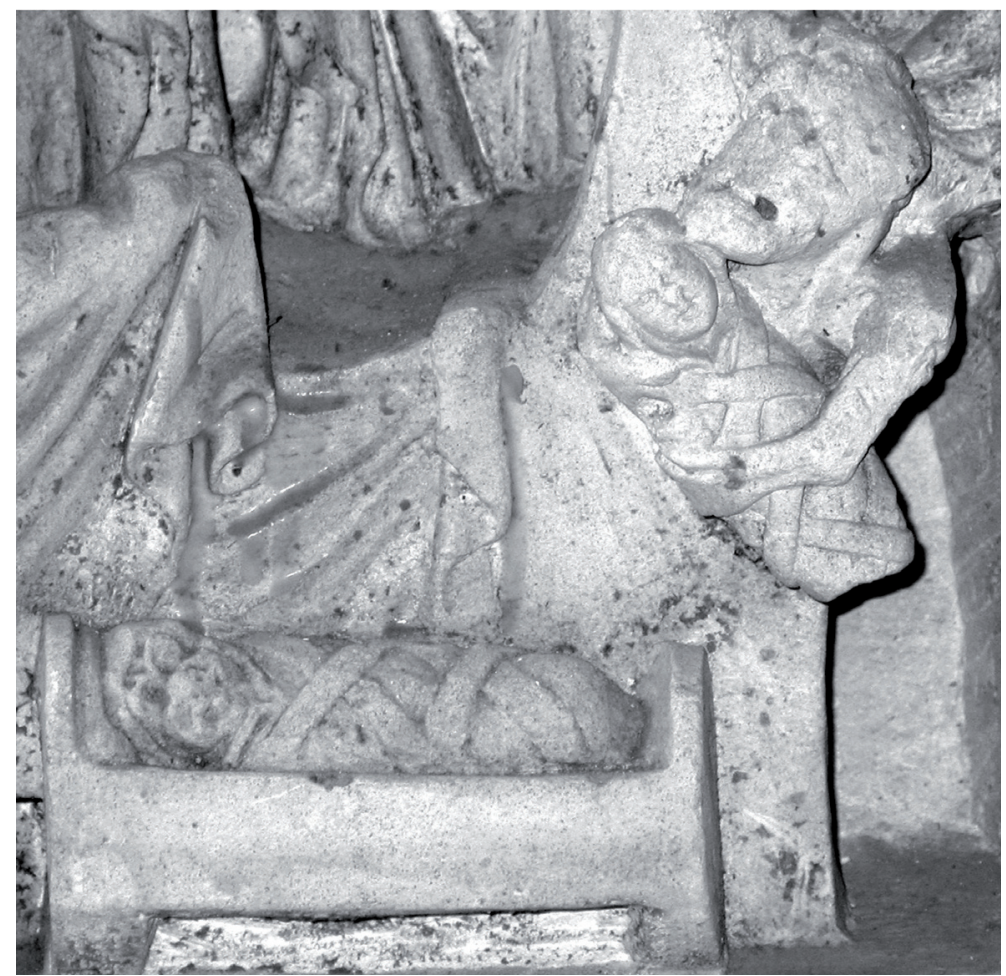

- Fig. 2. Rapto de S. Bartolomeu, trocado no berço por um bebé-demónio. Túmulo do rei D. Pedro I, c.1361-63. Mosteiro de Alcobaça, Portugal. 


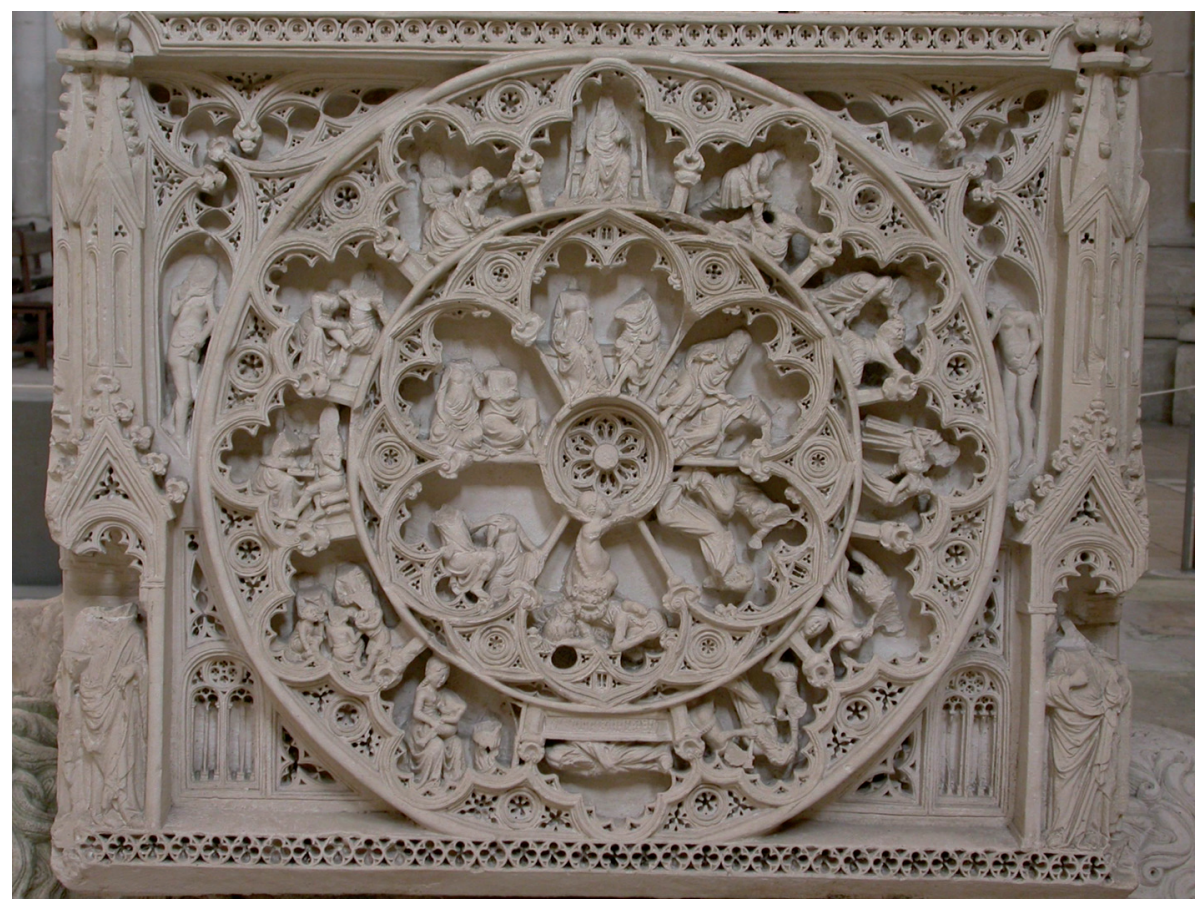

- Fig. 3. Roda da Vida e da Fortuna. Túmulo do rei D. Pedro I, c.1361-63. Mosteiro de Alcobaça, Portugal.

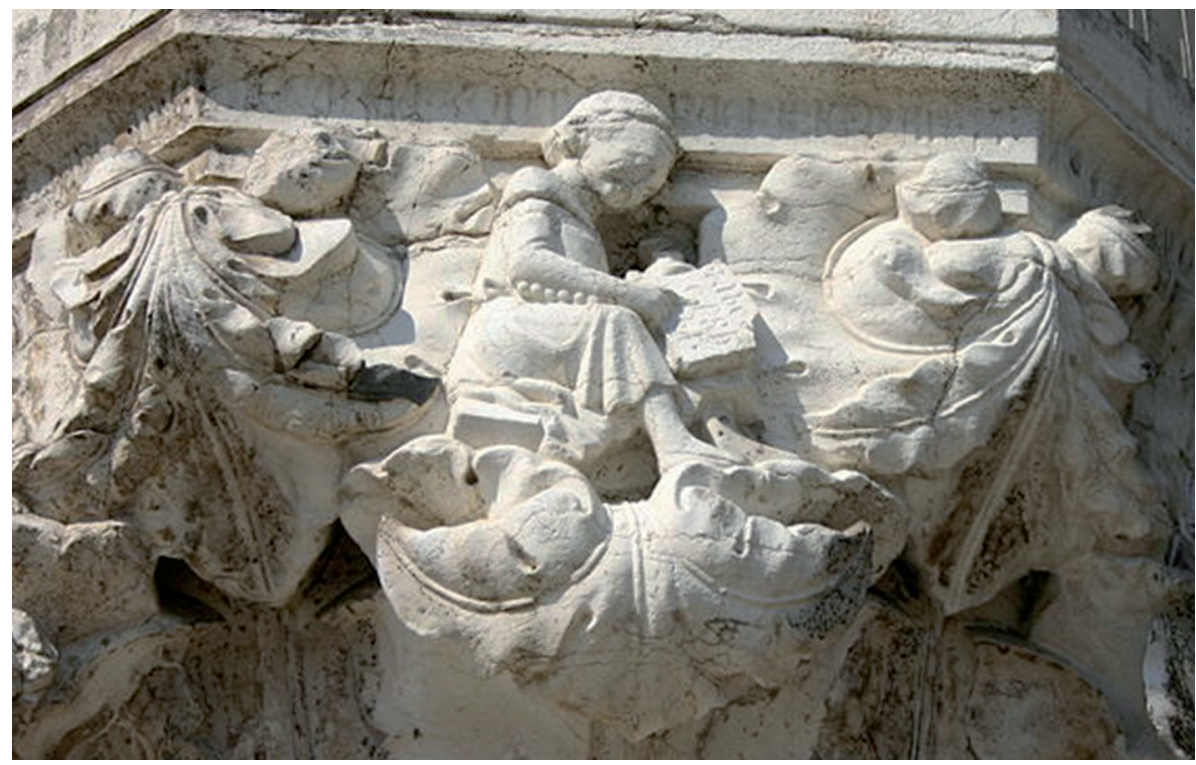

- Fig. 4. Puerícia. Capitel octogonal da galeria térrea do Palácio dos Doges, c.1342-48, Veneza, Itália. 


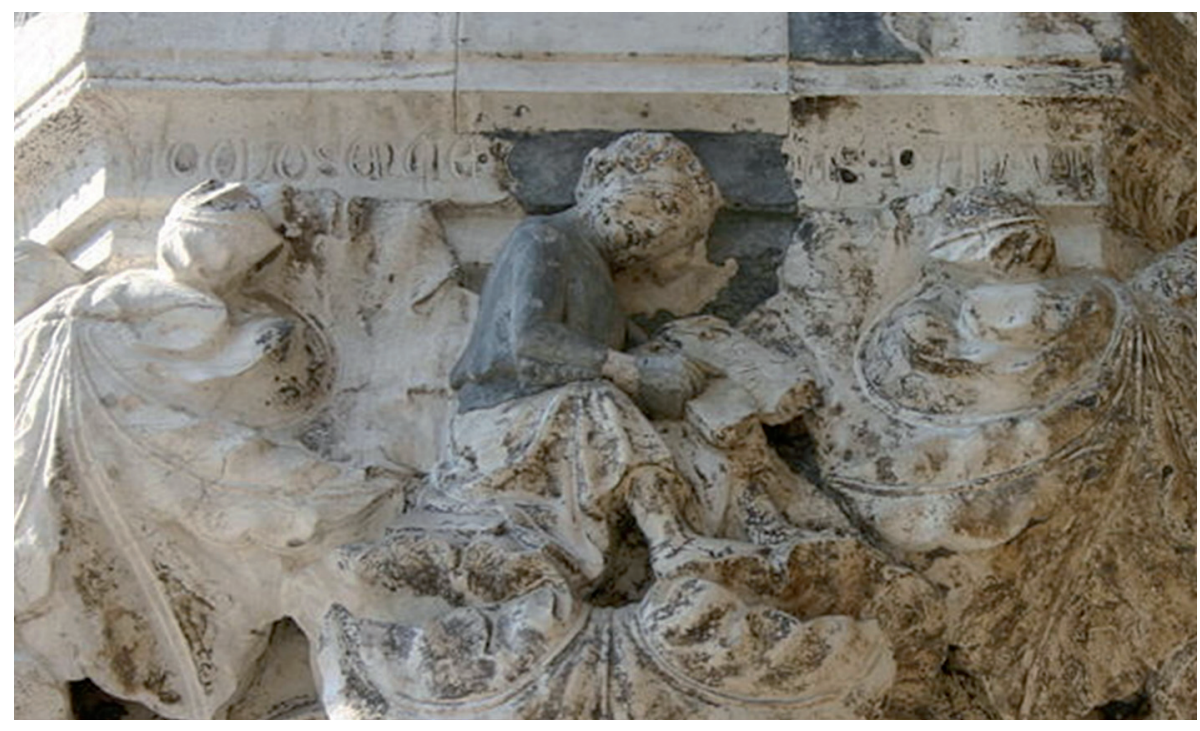

- Fig. 5. Adolescência. Capitel octogonal da galeria térrea do Palácio dos Doges, c.134248. Veneza, Itália.

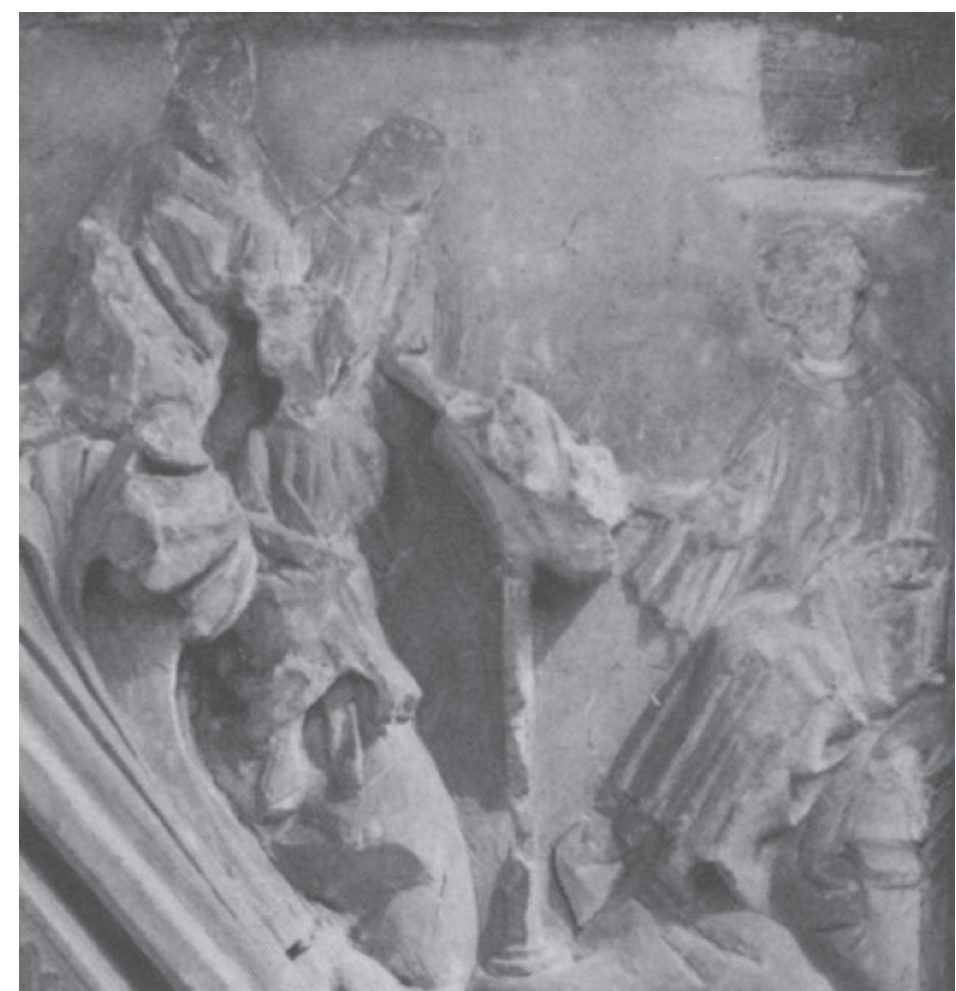

- Fig. 6. Cena escolar. Enjunta do monumento funerário do bispo Giles de Bridport, c.1270-80. Salisbury, Inglaterra. 


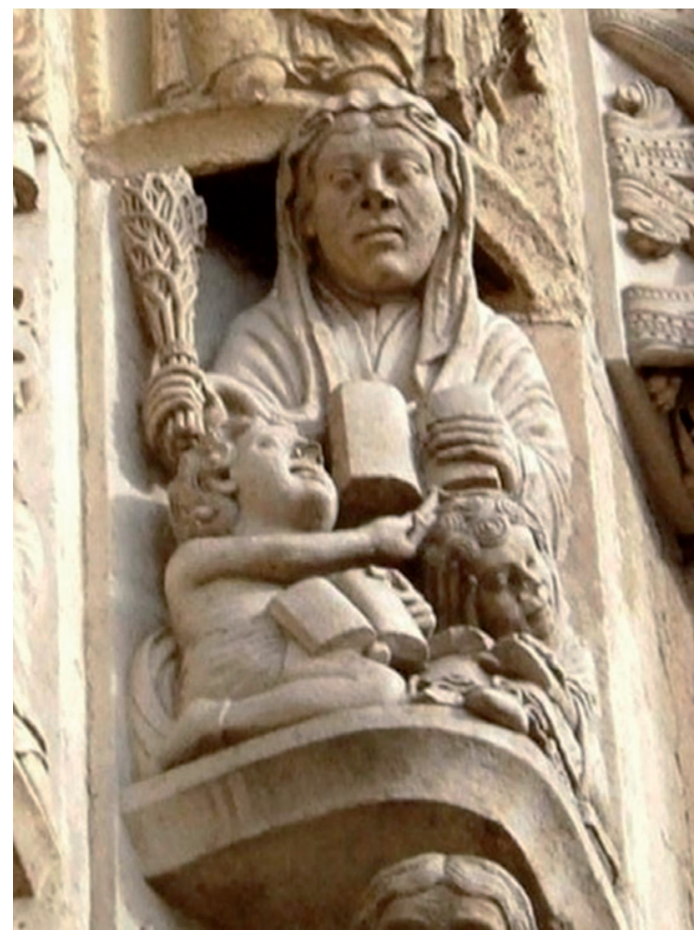

- Fig. 7. Gramática. Portal da fachada ocidental da catedral de Chartres, c.1145-50. Chartres, França.

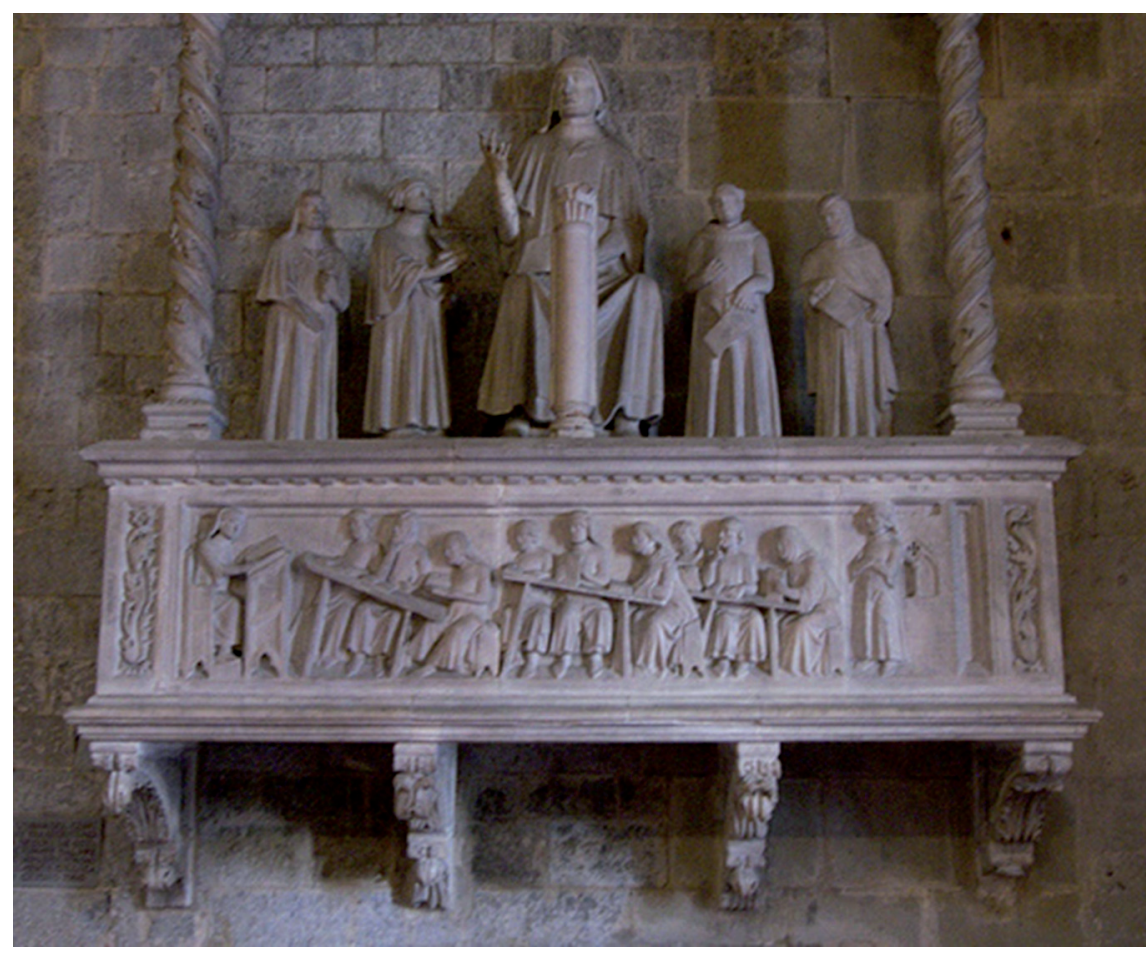

- Fig. 8. Túmulo de Cino da Pistoia. Catedral de Pistoia, c. 1336. Pistoia, Itália. 